\title{
RENT CONTROL IN THE PATENT DISTRICT: OBSERVATIONS ON THE GRADY-ALEXANDER THESIS
}

\author{
Robert P. Merges*
}

TNTELLECTUAL property-especially patents-is a largely utilitarian discipline. So it is surprising that law and economics scholars such as Mark Grady and Jay Alexander are only now turning their attention to this fascinating and sometimes arcane field. But, late as it inay be, this is a development that will be welcomed. At least if their article ${ }^{1}$ in this issue is any indication, those of us interested in patents-some of whom have made stabs in this directioncan look forward to a stimulating stream of fresh ideas.

Grady and Alexander's central idea is so fresh, in fact, it may need a few more minutes im the oven. The authors assert that the important patent decisions since the nineteenth-century have attempted to minimize rent dissipation in the patent system. As I will try to explain, I believe this opens up a new and important window into certain patent law doctrines. At the same time, I beheve some of its broader claims need to be pruned back. These reservations should not, however, detract from my main point, which is that ideas such as the rent dissipation thesis make a profound contribution to the field.

\section{THE BASIC IDEA}

Grady and Alexander contend that the patent system strives to minimize rent dissipation at three stages: when an inventive idea is conceived; after an invention has been cominercialized and other imventors are attempting to improve on it; and, finally, when an inventor is deciding whether or not to keep an imvention secret. ${ }^{2}$

* Associate Professor of Law, Boston University. Professor Merges wishes to extend his gratitude to all those associated with the John M. Olin Foundation at the University of Virginia, with particular thanks to Professors Douglas L. Leslie and Edinund W. Kitch. For a nore complete discussion of nuany of the ideas in this comment, see Robert P. Merges, Patent Law: Cases and Commentary (forthcoming 1992).

1 Mark F. Grady \& Jay I. Alexander, Patent Law and Rent Dissipation, 78 Va. L. Rev. 305 (1992).

2 Id. at 308-10. 
At every stage, Grady and Alexander argue, the patent system seeks to discourage wasteful activities contributimg hittle or nothing to social welfare. In the first stage, idea conception, "dreamers" might waste resources miagining and filing for "conceptual" patents with no basis in existing technology. ${ }^{3}$ Various patent law doctrines-most centering around the enablement principle of $\S 112$ of the Patent Code $^{4}$-prevent this. At the second stage, when follow-on inventors race each other to find improvements on a basic invention, rents are dissipated through the resources spent on the race. Grady and Alexander suggest that the goal of another group of patent rules defining the effective scope of a patent is to minimize losses from such races. ${ }^{5}$ Finally, when an inventor faces the precommercialization stagewhich may not be third temporally, but which Grady and Alexander treat as less important than the other two-resources inay be wasted by excessive investments to keep technology secret. ${ }^{6}$

Each stage reflects a different dimension of the common theme of rent dissipation. According to Grady and Alexander it is the minimization of this dissipation - the prevention of wasteful expendituresthat really explains what patent law is trying to do. In this sense, the basic idea is to abstract away from particular doctrines that a court discusses and see the larger context. This maneuver has the virtue of all useful theory: it cuts through a great deal of detail, and focuses attention on a few individual features in the cases.

\section{RENT Dissipation, ENABlemENT, AND NonObViousness}

There are several areas where the virtues of the Grady-Alexander hypothesis are especially clear. The first and most important of these is the area of enablement. ${ }^{7}$ In patent law, a patent application must disclose enough to enable someone skilled in the art to make and use the invention clamied in the patent. A patentee must enable someone else to put into operation all the embodiments of the invention she claims coverage for in her patent. This requirement can at times be applied rather loosely; a specification that supplies little guidance on

3 Id. at 307-08.

435 U.S.C. $\S 112$ (1988).

5 Grady \& Alexander, supra note 1, at 318-21.

6 Id. at 308-09, 317-18, 341-42.

7 The following discussion is adapted from Robert P. Merges \& Richard R. Nelson, On the Complex Economics of Patent Scope, 90 Colum. L. Rev. 839, 845 (1990). 
the subject matter at the fringes of a patent's claims is often sufficient. $^{8}$

Patent commentators have puzzled over the contours of this requirement for a long time. ${ }^{9}$ At first blush it might seem to make sense to limit a patentee to only those embodiments of the invention disclosed by the specification, in other words, those that she has actually achieved at the time the patent application is filed. But imitators would soon find some minor variation over the disclosed einbodiinents; a nonenablement defense would then insulate the imitators from an enforceinent action by the patentee. Such a rule, it has been agreed, would soon render patents useless.

Consequently, it is generally acknowledged that a patent's claims need not be restricted to the particular einbodiment of the invention described in a patentee's specification. Many cases illustrate that a patent's specification need not explain precisely how to inake every device falling within its claims. ${ }^{10}$ Disclosure of an inventive concept or principle whose precise contours are defined by the claims is enough. ${ }^{11}$ But surely one can go too far. Although as a general rule a patentee should be able to claim beyond her precise disclosure, current practice permits a range of claims stretching beyond the spirit of the enablement doctrine. ${ }^{12}$ If the patent examiner can use the prior art to show that soine embodiments of the claimed invention will be impossible to inake without inore information than the inventor (or anyone else) knows, the claims will be narrowed. But if the examiner

\& See, e.g., In re Strahilevitz, 668 F.2d 1229, 1232 (C.C.P.A. 1982) (upholding a patent where the applicant had never tested a working model); see also Patrick Kelly, Prophetic Patents in Bioteehnology, 8 Bio/Tech. 24, 25 (1990) (discussing the Strahelivetz patent and the potential it holds for biotechnology inventors to file patents before obtaining actual working examples of their inventive concepts); cf. Precision Metal Fabricators, Inc. v. Jetstream Sys. Co., 6 U.S.P.Q.2d (BNA) 1704, 1709 (N.D. Cal. 1988) ("The enablement requirement does not require that the patent disclose the specific embodiment of the claim; a broad claim can be enabled by the disclosure of a single embodiment.").

9 See, e.g., Samuel S. Levin, Broader than the Disclosure in Chemical Cases, 31 J. Pat. Off. Soc'y 5 (1949); Ellen P. Winner, Enablement in Rapidly Developing Arts-Biotechnology, 70 J. Pat. \& Trademark Off. Soc'y 608 (1988).

10 See, e.g., Merges \& Nelson, supra note 7, at 845-52.

11 It is important to distinguish my use of the term "principle" here from its use in other contexts. I mean primciple in the narrow sense of an underlying characteristic that gives a family of devices an identifiable quality. I do not mean a scientific or natural primciple, in other words, a broadly applicable law such as gravity or magnetism, which cannot be patented. See Gottschalk v. Benson, 409 U.S. 63, 67 (1972).

12 Merges \& Nelson, supra note 7, at 848. 
cannot single out a reason why the claims seem too broad, the applicant has a good chance of receiving broad coverage.

The enablement principle has proven very difficult to apply in practice. Grady and Alexander, however, may have helped the situation with their rent dissipation concept. The most useful aspect of their thesis, for purposes of enablement analysis, is the notion of "signaling." They state several times that courts have implicitly focused on the range of improvements signaled by a patent. If a patent signals a broad range of improvements, courts have found that its scope should be broad; this explains a myriad of cases, ranging from Rubber-Tip Pencil Co. v. Howard ${ }^{13}$ to The Telephone Cases. ${ }^{14}$

The value of this approacli is that it subtly shifts the empliasis of traditional enablement analysis. Traditionally, courts have asked whether one "skilled in the art" can read the inventor's specification and build all the embodiments of the invention claimed. If so, the enablement requirement is met. Grady and Alexander shift tlie focus of the test to ask not whetlier a skilled artisan can duplicate all the claimed versions of the patentee's invention, but whether the patentee's specification signals the possibility for myriad improvements. Although in many cases the two tests amount to the same thing, in a few they do not, and these cases strike me as significant.

Consider, for instance, a longstanding patent conundrum. Inventor $A$ comes up witl a pioneering imvention in a certam field and obtains a patent witl broad claims. Now $B$ comes along and imvents an improvennent on $A$ 's invention, or a specific application of $A$ 's technology. $B$ applies for a patent, and receives it. Later, $A$ discovers that $B$ has begun to commercialize her imvention. $A$ sues $B$ for infringe1nent. $B$ argues that her invention cannot possibly infringe $A$ 's, because the Patent Office lias granted her $(B)$ a separate patent on her invention. $A$ argnes that simply because $B$ 's invention met the requirements for patentability-namely that it was novel, useful, and nonobvious-does not mean that it does not infringe $A$ 's patent. Implicit in $B$ 's argument is the point that $B$ 's invention cannot infringe, because it is not enabled by $A$ 's specification; if it were it would be obvious in light of that specification, and lience unpatent-

1387 U.S. (20 Wall.) 498 (1874).

14126 U.S. 1 (1888). 
able over $A$ 's pre-existing patent. The very fact that $B$ received a patent undermines $A$ 's claim that $B$ 's invention infringes.

When this situation actually arose recently, the United States Court of Appeals for the Federal Circuit ruled in favor of $A$, holding that $B$ 's nivention infringed $A$ 's patent. ${ }^{15}$ But the decision was not without conceptual difficulty, owing to the seeming inconsistency between an invention's being admittedly nonobvious and yet infringing. The tension arises because for another invention to infringe, that invention inust be within the scope of the patent's claims, and every embodiinent within a patent's claims inust be at least generally enabled by that patent's specification. ${ }^{16}$ To grasp the conundrum, keep in mind underlying rationales of enableinent and nonobviousness. The foriner

15 Atlas Powder Co. v. E.I. Du Pont de Nemours \& Co., 750 F.2d 1569, 1579 (Fed. Cir. 1984). To be specific, the court held that it infringed not "literally" but under the "doctrine of equivalents." Id. For more on this, see Merges \& Nelson, supra note 7, at 852-68; see also In re Fisher, 427 F.2d 833 (C.C.P.A. 1970), where the court in dictum said:

It is apparent that [such an imventor of a basic technologyl should be allowed to dominate the future patentable inventions of others where those imventions were based in some way on his teachings. Such improvements, while unobvious from his teachings, are still within his contribution, because the improvement was made possible by his work.

Id. at 839 (emphasis added). This suggests a more traditional legal fornulation of the "signaling" notion-that the basic invention be a "but-for cause" of the improvement, although not necessarily the proximate cause.

16 The Atlas Powder case was deeided on the basis of the doctrine of equivalents. It often has been stated that what will count as an equivalent, for infringement purposes, is determined in much the same way as the question of whether a patent applicant adequately enabled the art as to her claims. See Graver Tank \& Mfg. Co. v. Linde Air Prods. Co., 339 U.S. 605, 609 (1950) (holding that an important determmant in the equivalents inquiry is "whether persons reasonably skilled in the art would have known of the imterchangeabihty of an ingredient not contained in the patent with one that was"); see also Great N. Corp. v. Davis Core \& Pad Co., 782 F.2d 159, 165 (Fed. Cir. 1986) (examining "the scope and content of the prior art, [and] the ordinary level of skill in the art [to determine if] ... the claimed subject inatter would not have been obvious to one of ordinary skill in the art at the time the invention was inade"); Thomas \& Betts Corp. v. Litton Sys., Inc., 720 F.2d 1572, 1579 (Fed. Cir. 1983) (noting that "the test of equivalency extends beyond what is literally stated in a patentee's specification to be equivalent and encompasses any element which one of ordinary skill in the art would perceive as interchangeable with the claimed eleinent"). But see Martin J. Adehnan \& Gary L. Francione, The Doctrine of Equivalents in Patent Law: Questions that Pennwalt Did Not Answer, 137 U. Pa. L. Rev. 673, 697 (1989) (arguing that interchangeability "should be used to rejeet rather than support the application of the doctrine of equivalents"). See generally Roy H. Wepner, The Patent Invalidity/Infringement Parallel: Symmetry or Semantics?, 93 Dick. L. Rev. 67, 74-77 (1988) (arguing that syminetry between rules governing infringement of a patent and those governing the decision to grant a patent will optimally benefit the parties involved and the public); Donald S. Chisum, Cominent: Anticipation, Enablement, and Obviousness: An Eternal Golden Braid, 15 AIPLA Q.J. 57 (1987) (arguing that it may be 
requires that the patentee place before the public a full and adequate description of the invention she claims; the latter requires that an invention represent a nontrivial advance over what was known before-including all prior patents, whose teachings naturally extend to the full range of their enabling disclosure. How could $B$ 's invention infringe $A$ 's patent when the Patent Office had determined that $B$ 's improveinent was a nontrivial extension of what was known in the art (it was nonobvious), including the teachings of $A$ 's patent?

Traditional doctrine has a difficult time coinfortably resolving this conundrum. The best that can be said is that the policies behind the enableinent and nonobviousness requireinents are different, so logical consistency must not be expected. The signaling coinponent of the Grady-Alexander thesis offers a new way of viewing the enablement doctrine-one that avoids the conundrum. The question becomes: has $A$ signaled the possibility of improvements such as the one $B$ made?

Under this approach, the scope of a patentee's claims turns on the range of teclinological possibilities signaled in the specification of the patentee's patent apphication. Perhaps it requires significant amounts of effort for $B$ to improve upon $A$ 's invention, because the improvement is nonobvious, but if $A$ signaled the possibility and importance of the sort of improvements $B$ made, then $B$ will not be permitted to assert that $A$ inadequately enabled the art in her patent. This shift in focus away from full and complete disclosure, toward the notion of signaling, represents a novel approach to enablement doctrine, at least in the context of improvement inventions. Although the full implications of this approach need to be worked out, no one should doubt that it is indeed a new departure.

The implications of the Grady-Alexander thesis are, however, not limited to enablement. It also has relevance for the nonobviousness doctrine of $\S 103$ of the Patent Code. ${ }^{17}$ As inentioned, this doctrine requires an inventor to show that her invention would not have been obvious to one with reasonable skill in the relevant art. Grady and Alexander recast the test, again in terns of signaling, asking whether there are any signals in the prior art suggesting the desirability or

possible for a patent to be both obvious and nonenabling, but not commenting on the problem of a patent that is both enabling and infringed by a nonobvious improvement).

1735 U.S.C. $\$ 103$ (1988). 
feasibility of making a particular invention. If so, that invention is obvious and hence unpatentable.

In one sense this merely restates the traditional approach. Wellestablished doctrine directs the Patent Office and courts to examine the prior art for indications that what the inventor did was desirable or feasible. Patentability often turns on whether the prior art sent such strong signals that a reasonably skilled imventor would liave expected a reasonable chance of success just prior to completing the invention. ${ }^{18}$ But the approach taken by Grady and Alexander might be useful in its own right, because it focuses on the work of the apphcant or patentee itself. If that work signals something new, soine new possibilities for improvement, it must be nonobvious. Rather than focusing on the effect the prior art had on the inventor, the signaling concept focuses on the effect the patentee's or apphicant's research is having on others skilled in the art. This might be useful in avoiding a major problein in the area of nonobviousness: the tendency to look back on the invention froin a time after it has been proven to workknown im patent shorthand as "the hindsiglit problem." The approach taken by Grady and Alexander tends to minimize this possibility, because it looks to the behavior of others in the field responding to the inventor's disclosure. If that disclosure sets off a race to find improvements, it is a safe bet that the inventor has disclosed soinething nonobvious. If hittle activity follows, or if activity follows the lead of some researcher other than the patentee, this supports the conclusion that the work of the patentee was obvious. Again, many of the same mdicia are examined in traditional approaches to nonobviousness, ${ }^{19}$ but Grady and Alexander simply focus attention more clearly on the notions of signaling and follow-on activity.

18 In a forthcoming paper, I explore the rationale behind this approach, concluding that nonobviousness is essentially designed to foster research with a low ex ante probability of success, and arguing that the policy behind the doctrine ought to extend to take account of research reasonably likely to succeed, altlough very costly to pursue. See Robert P. Merges, Uncertainty and the Standard of Patentability (1991) (working paper on file with the Virginia Law Review Association).

19 See Robert P. Merges, Commercial Success and Patent Standards: Economic Perspectives on Innovation, 76 Cal. L. Rev. 803, 831-32 (1988). 


\section{RENT DISSIPATION AS AN EXPLANATORY VARIABLE}

Although the contributions of the Grady-Alexander thesis just outlined are significant, they are only the tip of the iceberg compared to the full aspirations of the thesis. Their ultimate aim is to explain the "notoriously unrehable" doctrines of patent law, which the authors describe as "judicial glosses." 20 Rent dissipation is the explanatory key. In support of their thesis, the authors review cases that, on their face, turn on a wide array of patent issues, such as: patentable subject matter (Funk Bros. Seed Co. v. Kalo Inoculant Co. ${ }^{21}$ Diamond v. Chakrabarty, ${ }^{22}$ Diamond v. Diehr, ${ }^{23}$ and Gottshalk v. Benson $\left.{ }^{24}\right)$; enablement ( $O$ 'Reilly v. Morse ${ }^{25}$ ); novelty and nonobviousness ( $R$ ubber-Tip Pencil Co. v. Howard, ${ }^{26}$ Wyeth v. Stone, ${ }^{27}$ Tilghman v. Proctor, ${ }^{28}$ Hotchkiss v. Greenwood, ${ }^{29}$ and Graham v. John Deere Co. ${ }^{30}$ ); and infringement (Graver Tank \& Manufacturing Co. v. Linde Air Products Co. $^{31}$ and Texas Instruments v. United States International Trade Commission ${ }^{32}$ ). Throughout, Grady and Alexander demonstrate admirable imterpretive skill as they seek to fit this diverse range of cases into their single-factor account.

Nevertheless, that account has shortcomings, two of which deserve comment. The first is that all the cases discussed turned on points miportant only for reasons internal to the doctrines actually employed. That is, the courts thought the particular doctrines at issue-be they patentable subject matter, nonobviousness, or infringement-provided the key to the various decisions. Only im retrospect does rent dissipation explain the outcomes. Nor do the authors claim otherwise; theirs is, they tell us, only a positive theory. The problem is that the doctrines that actually decided the cases might well have

\footnotetext{
20 Grady \& Alexander, supra note 1, at 305.

21333 U.S. 127 (1948).

22447 U.S. 303 (1980).

23450 U.S. 175 (1981).

24409 U.S. 63 (1972).

2556 U.S. (15 How.) 62 (1854).

2687 U.S. (20 Wall.) 498 (1874).

2730 F. Cas. 723, 725 (C.C. Mass. 1840) (No. 18,107).

28102 U.S. 707 (1880).

2952 U.S. (11 How.) 248 (1850).

30383 U.S. 1 (1966).

31339 U.S. 605 (1950).

32805 F.2d 1558 (Fed. Cir. 1986).
} 
led to different outcomes under shightly different facts-none of which need concern the degree of rent dissipation attending the circumstances.

In Tilghman, for instance, the authors find sohd support for their thesis; the patent was upheld, they inform us, because the inventor had opened up the possibility of a considerable number of improvements in the art of rendering animal fats. ${ }^{33}$ Yet that case actually turned on whether a prior invention duphicated the results of the mvention at issue. The Court held that indeed it did, but because the prior art invention had only accidentally (and unobtrusively) reproduced the effect claimed in the patent at issue, the patent was not invalid for lack of novelty. ${ }^{34}$ Tilghman is thus a benchmark case in the area of accidental or unintended anticipation. If the creator of the prior art invention had, contrary to the actual facts, recognized that his device regularly produced the same cheimical effect later claimed by Tilghman, the patent would have been invalid. What is critical is that this conclusion does not change simply because of the presence or absence of potential improveinents flowing from the patentee's invention; the same number of improvements-hence opportumities for rent dissipation-are possible. The only difference is that the patent would not have been upheld, unless the Court had adjusted the doctrine to reach this resnlt.

The second inajor problem with the broad reach of the GradyAlexander thesis is that some of the cases they review and explam very likely would come out the opposite way under contemporary doctrine. This puts the authors in an uncomfortable position, because they are purporting to describe a inerely positive theory. Explanimg cases that are no longer good law coines perilously close to prescribing a norinative theory, one which would change contemporary doctrine back to what it was under the older cases. The authors are thus in a position similar to that of Pope John XXIII's advisors, who supposedly had to convince him after he became Pope that he was now infallible. Grady and Alexander must likewise tell the United States Supreme Court that it always gets the patent cases right-or at least, that it always has in the past. By explaining the pattern of past cases,

33 Grady \& Alexander, supra note 1, at 324-25.

34 Tilghman v. Proctor, 102 U.S. 707 (1880). 
they leave no room for the Court-or inferior courts following its direction-to change the law in accordance with future developments.

A good example is Funk Bros., ${ }^{35}$ where the Court invalidated a patent for a new mixture of bacteria used to imduce nitrogen fixation im plant roots. Some commentators beheve that although the Court phrased its holding in terms of patentable subject matter, the case actually turned on what we would now call nonobviousness. ${ }^{36}$ In any event, unlike Grady and Alexander, who justify the Court's holding by explaining that the nivention likely exhausted the field of bacteriatreatment for this purpose, it is quite arguable that today's Court would decide the case differently. The fact that the imvention covered living subject matter would be irrelevant post-Chakrabarty, ${ }^{37}$ and the prior art would be scoured for any nidication of whether it suggested the feasibility or desirability of the combination of bacteria claimed by the inventor. ${ }^{38}$ It appears there was no such suggestion. As a consequence, the patent would likely be upheld, and the rent dissipation account would no longer be accurate.

But note that under this scenario, ouly the doctrime has changed; all the other features of the case stay the same. The invention still sends the same signal to other inventors; the same opportunities for improvement would be present; the same low degree of rent dissipation would follow fron imvalidating the patent. Yet because the doctrime so dictated, the patent likely would be upheld. In other words, rent dissipation no longer explains the outcome. This puts Grady and Alexander to a choice: either modify their analysis of how much rent dissipation was really nivolved, or convert their theory into a normative one directing the courts to alter doctrime to nivalidate such patents.

Another example is Risdon Iron and Locomotive Works v. Medart. ${ }^{39}$ Although Grady and Alexander correctly note that the mvention may have been obvious, the Court nivalidated the patent

35 Funk Bros. Seed Co. v. Kalo Inoculant Co., 333 U.S. 127 (1948).

36 See, e.g., 1 Donald S. Chisum, Patents § 1.02[7][b], at 1-37 (1978 \& Supp. 1990).

37 Diamond v. Chakrabarty, 447 U.S. 303 (1980).

38 See, e.g., In re O'Farrell, 853 F.2d 894, 902 (Fed. Cir. 1988); Application of Winslow, 365 F.2d 1017, 1020 (C.C.P.A. 1966); see also U.S. v. Adams, 383 U.S. 39, 51 (1966) (combination of old elements known in the art that produced surprising results may meet nonobviousness requireinent of patentability).

39158 U.S. 68 (1895). 
because it claimed "the function of [a] machine."40 Risdon was one in a series of cases grappling with the patentable nature of processes. As Grady and Alexander point out, the Court eventually discarded the "function of a machine" rule; now a claim will be upheld if it describes a particular process, such as "the process of lifting heavy objects using a lever of approximately such-and-such dimensions." A claim will be struck down if it covers an entire end-result, such as "the process of lifting heavy objects using a lever." $R$ isdon was one step in the evolution of this rule. If $R$ isdon had coine later, the patent might have been upheld. Although the Court might have found another rationale for invalidating it-giving voice to the unarticulated urge to minimize rent dissipation-it is possible that it would not have done so. If not, the Grady-Alexander thesis is once again put to the test: adapt to the different outcoine, or adopt a normative cast.

\section{COMMENTS ON THE IMPLICIT MODEL}

In a sense, quibbling with the doctrinal details of individual cases does the Grady-Alexander thesis a disservice, for its imphications go far beyond merely tidying up loose doctrimal ends. Rather, it seeks a streamlined explanation of the essence of the patent systein. To get at this deeper significance, one needs to move beyond individual cases to a discussion of the inodel of techincal advance and rent dissipation imphicit in the Grady-Alexander thesis.

At the heart of the thesis is its conception of technological opportumities. For the most part, these can be thought of as the techirical embodiments of the inventive primciple disclosed in a patent, as well as miprovenents to and applications of that primciple. The notion of signaling is once again the key: the thesis asks, what does the patent tell the art about potentially feasible follow-on inventions? If the answer is "a great deal," the thesis states that it ought to receive a patent, and that the patent ought to have a wide scope. If very few follow-on inventions are signaled, the thesis dictates that the patent ought not be granted at all.

Imphicit in this approach is a model of teclinical advance with two important attributes. First, teclinological opportunities are assets like any other. They are out there in fixed numbers, waiting to be cap-

40 Id. at 84.

41 Chisum, supra note $36, \S 1.03[7][\mathrm{c}]$, at $1-165$. 
tured by those willing to expend the resources necessary to garner them. Second, the creator of an mvention suggesting a broad range of follow-on improvements is in at least as good a position to develop those improvements as potential competitors. Thus, it is reasonable to allow a broad scope of protection to that imitial inventor; we can expect her to develop the improvernents at least as quickly and efficiently as her competitors. And, of course, we avoid the wasteful duphication that necessarily comes with a race by coinpetitors to improve the imitial invention.

This view of technical advance closely tracks the hiterature describing invention as a "common pool" problem. In this hiterature, invention is compared to fishnig froin a common pool. ${ }^{42}$ There are many competitive inventors, and the first to make an invention gets the patent on it. Each knows that as others catch (invent) there is less in the pool for her. The result is "overfishnig:" too many people seeking inventions at once. ${ }^{43}$ Other inodels have extended and refined this analysis by analyzing inultifirm "races to patent," in which inany would-be inventors identify a particular goal, and the first to achieve the goal gets the patent. ${ }^{44}$ A good deal of variation and sophistication has been introduced into these inodels, as assumptions such as the strength of patents and the costs and benefits of innovating versus innitating have been relaxed. ${ }^{45}$ Even with these refinements, articles in

42 See Merges \& Nelson, supra note 7, at 870.

43 See, e.g., Pankaj Tandon, Rivalry and the Excessive Allocation of Resources to Research, 14 Bell J. Econ. 152 (1983) (excessive duplication of research results when competitors race for "common" result that will be covered by a strong property right).

44 See, e.g., Partha Dasgupta and Joseph Stiglitz, Uncertainty, Industrial Structure and the Speed of R\&D, 11 Bell J. Econ. 1, 12-13 (1980); Glenn C. Loury, Market Structure and Innovation, 93 Q.J. Econ. 395 (1979); Frederic M. Sclierer, Research and Development Resource Allocation Under Rivalry, 81 Q.J. Econ. 359, 364-66 (1967). For recent treatments of the topic, see Steven A. Lippman \& Kevin F. McCardle, Dropout Behavior in R\&D Races with Learning, 18 Rand J. Econ. 287 (1987). See generally Brian D. Wriglit, The Resource Allocation Problem in R \& D, in The Economics of R \& D Policy 41, 50 (George S. Tolley, James H. Hodge \& James F. Oehmke eds., 1985) ("The dissipation of the benefits of research by the competitive production of inventions before the socially optinnal time . . . is a dynamic intertemporal version of the same type of market failure [described in the common pool models].").

45 See, e.g., Partha Dasgupta, Patents, Priority and Imitation or, The Economics of Races and Waiting Games, 98 Econ. J. 66, 74-78 (1988) (exploring conditions that make waiting more profitable than entry in races to invent); Michael L. Katz \& Carl Shapiro, R \& D Rivalry with Licensing or Imitation, $77 \mathrm{Am}$. Econ. Rev. 402 (1987) (exploring effects of post-mvention dissemination, in other words, licensing or imitation, on two-firm strategic race to invent). 
this literature often conclude that there is unnecessary duplication of inventive efforts, or that inventive efforts are unduly rushed, or both. In short, these models tell the familiar tale of rent dissipation, at least where the "pool" containing the invention is large enough. The solution is to grant property rights to those fishing in the pool. This avoids duplication of effort and overfishing.

\section{Sketch of an Alternative Model}

These models-of which the rent dissipation thesis is a varianthave a basic slortcoming: they view technology as just another resource, subject to the same dynamics that govern any cominon pool situation. But the real problein with technology, as I and Richard Nelson argue in a recent article, is not controlling overfishing, but preventing underfishing after the right lias been granted. ${ }^{46}$ If a property right on a basic invention covers a host of potential improvements, the property right holder can be expected to develop the basic invention and some of the improvements. But we would expect a single rightholder to underdevelop-or even totally ignore-many of the potential improvements encompassed by the broad property right. ${ }^{47}$

There are several reasons why underdevelopment of patented inventions is likely to occur. First, althougl it may well be optimal for a firm to develop all the prospects encompassed by its riglit, it is more realistic to believe that firms will adopt a "satisficing" approach. ${ }^{48}$ Invention and development are notoriously uncertain activities; ${ }^{49}$ because many resources are often required to develop the

46 Merges \& Nelson, supra note 7, at 870,873 . The discussion that follows is adapted from a portion of this article; see id. at $870,872-77$.

47 Id. at 873-74.

48 This concept originated with economist Herbert A. Simon. See Herbert A. Simon, Theories of Decisionmaking in Economics, 49 Am. Econ. Rev. 253, 262-65 (1959); see also James G. March \& Herbert A. Smion, Organizations 141 (1958). This view is reflected in the work of some analysts of innovation:

The sluggishness of large firms in certain innovations has been explained by the desire to protect an investment in the then-current technology, satisfaction with the status-quo, underestimation of the potential demand for a new item, neglect of the inventor, and misdirection of research, as well as by incompatibility of bureaucracy and creativity.

Morton I. Kamien \& Nancy L. Schwartz, Market Structure and Innovation 68 (1982).

49 Christopher Freeman, The Economics of Industrial Innovation 148-50 (2d ed. 1982); Edwin Mansfield, John Rapoport, Jerome Schnee, Samuel Wagner \& Michael Hamburger, Research and Innovation in the Modern Corporation 9 (1971). 
first one or two applications of a basic invention, ${ }^{50}$ a rational organization can be expected to limit its attention to those one or two projects.

Second, once a firm has successfully developed and inarketed the first one or two applications of a pioneering invention, it often will begin to focus its attention on technical improvernents in those lines of business. As it builds up expertise and incurs sunk costs in one field, it inay choose to slow its investigation of other fields (or ignore thein altogether), especially the riskier ones. ${ }^{51}$ Again, it inay "satisfice," by deciding that current profit levels and inarket expansion rates are "good enough." Consequently, the firm inay take inuch niore time to develop the third application of the product tlian it took for the first two. ${ }^{52}$ Finally, the firm inay inadvertently overlook certain applications, the risk of liaving an organizational "single mind"

50 Cf. Edwin Mansfield, Mark Schwartz \& Samuel Wagner, Imitation Costs and Patents: An Empirical Study, 91 Econ. J. 907, 908-09 (1981) (study of 48 major innovations in chemical, drug, electronics, and machinery industries, 30 of which cost more than one million dollars and 12 of which cost more than five million dollars).

51 It has been argued that lack of rivalry can lead to a much slower rate of innovation than would otherwise be the case. See Michael E. Porter, The Competitive Advantage of Nations 170 (1990) ("Loss of domestic rivalry is a dry rot that slowly undermines competitive advantage by slowing the pace of mnovation and dynamism."). See generally Reuven Brenner, Rivalry: In Business, Science, Among Nations 17-18 (1987), where Brenner describes a broad and somewhat iconoclastic view of entrepreneurship, as an activity brought on by frustration and adversity - the need to take a gamble. He points out that an imcrease in rivalry can bring about these conditions, and thus he ties increased rivalry and competition to increased innovation. Id.

52 The transition from entrepreneur to an established, cautious firm can be breathtakingly fast. An historian who studied the beginning of the eleetrical lighting industry in the Umited States pointed out that in 10 years, Thoinas Edison changed from a maverick trying to get incandescent lighting accepted as feasible, to a staunch opponent of the "dangerous" innovation of alternating current. Harold C. Passer, The Eleetrical Manufacturers 1875-1900, at 174 (1953). The same phenomenon has been noted repeatedly. See, e.g., F.M. Scherer, Invention and Innovation in the Watt-Boulton Steam Engine Venture, 6 Tecli. \& Culture 165, 174 (1965), quoting a letter from James Watt, inventor of the steam engine, to his partner James Boulton:

On the whole, I find it now full tinne to cease attempting to invent new things, or to attempt anything whicl is attended with any risk of not succeeding, or of creating trouble in the execution. Let us go on executing the things we understand, and leave the rest to younger men, who have neither money nor character to lose.

See also Kamien \& Schwartz, supra note 48, at $74-75$ (positing alternative explanations of why innovators stop innovating: "Either initial success leads to complacency or the suceessful firm is not as hungry as the newcomer or the behavior that led to the first success is maintained until it becomes obsolete in a changing environment."). 
working on a problem. ${ }^{53}$ Invention of improvements, like all invention, is an expensive and unpredictable activity, ${ }^{54}$ and the more approaches that are tried the more likely it is that technical advances will be made.

In all these ways potential applications of the basic invention covered by a broad property right may go unexplored. Notice too that an exceptional inventor who does explore many applications lias a natural advantage over competitors, due to ler early start. Granting narrower riglits at the margin will not slow down this imventor in the least; slie simply will seek a series of improvement patents in addition to her original patent. This is another way of saying that the coinpetition for improvements naturally will involve tle original inventor as well as ler competitors.

Unlike rights that somehow touch tangible property-the usual subject of the common pool analysis-the allocation of property

53 See Richard R. Nelson \& Sidney G. Winter, An Evolutionary Theory of Economic Change 389 (1982). To the extent the holder of a broad patent has market power, it is relevant to note that analysts of monopoly power often comment on the monopolist's reduced incentives to innovate. See Kemieth J. Arrow, Economic Welfare and the Allocation of Resources for Invention, in 5 Collected Papers of Kenneth J. Arrow: Production and Capital $104,114-17$ (1985) (concluding from inodel that the monopolist's incentive to innovate is less than the inventor in competitive industry); Kamien \& Schwartz, supra note 48, at 29-30 (1982):

The firm presently realizing monopoly profits may be less motivated to seek additional profits than the one earning only normal profits. It may, in other words, be less hungry for additional profits than the firm without a monopoly position. Several reasons for this are possible. First, it may begin to regard additional leisure as superior to additional profits ..... Second, it may becoune more concerned with protecting its current monopoly position than acquiring a new one.

54 Many improvements are patentable, suggesting that significant improvements involve a great deal of independent imventive contribution. A study of the history of innovations in almost any field will show the key importance of improvement inventions. One good source of such studies is Eric von Hippel, The Sources of Innovation 131-207 (1988) (innovation histories of 12 industries). For example, among von Hippel's descriptions of innovations in scientific instruments, he describes the invention of the gas chromatograph, id. at 134-35, and then details the following improveinents: temperature programming, capillary columns, salinization ("a major step forward"), argon ionization (patented), electron capture deteetor, flame ionization detector (patented), mass speetrograpl linkage (patented), and process control interface. Id. at 135-41. Similarly, von Hippel describes the invention of nuclear magnetic resonance ("NMR") imaging, id. at 143, and then describes four major improvements. Id. at 145-49. The same pattern holds true for all his innovation histories. Although von Hippel does not directly compare the difficulty-lience cost-of improveinent inventions, it is clear from his descriptions that many of the improvements were significant technical achievements. Thus, cost and difficnlty can be inferred. 
rights between technological pioneers and improvers is not a zero-sum game. In fact, it is the positive-sum aspects of allowing more competition for improvements that lead me to advocate narrowing the scope of the imitial inventor's patent. In addition, of course, are the wellknown problems of transaction costs; it seems whimsical to assume that all improvers and potential improvers will be able to bargain with the holders of pioneering patents. ${ }^{55}$ Without such bargaining, the exchange mechanism on which property rights literature rehes so heavily cannot work. ${ }^{56}$

This difference between patent and tangible property rights leads to a related point: There are significant problems with a system of rights that assumes complementary inventors can be tapped for improvements via selective hicensing practices. A substantial hiterature documents the steep transaction costs of technology hicensing, ${ }^{57}$ and there is indirect evidence that these costs imcrease when major innovations

55 Imagine the magnitude of these costs: identifying all the prospective improvers; agreeing on the value of the pioneering invention and the expeeted value of the improvement; and finding an acceptable division of profits from the "surplus" created when the improvement is combined with the pioneer invention. For some background on the strategic aspects of hicensing transactions, see Francis Bidault, Technology Pricing: From Principles to Strategy (Brian Page \& Peter Sherwood trans., 1989); see also Michael J. Meurer, The Settlement of Patent Litigation, 20 Rand J. Econ. 77, 77 (1989) ("patent validity disputes are not always resolved with hicensing agreements because of ineentive problems created by private information about validity."). For a heroic effort to imagine a world where these costs are manageable, see Ben T. Yu, A Contractual Remedy to Preinature Innovation: The Vertical Integration of Brand-Name Specific Research, 22 Econ. Inquiry 660 (1984) (argning first that current property rights encourage "rushing" of innovation, and second that there is a contractual solution, whereby manufacturers form pre-invention contracts with prospective inventors). On the effect of multiple bargainers, see generally Robert D. Cooter, Coase Theorem, in 1 The New Palgrave: A Dictionary of Economics 457, 458 (1987) (example of many farmers in Coase's famous fariner-railroad bargaining hypothetical).

56 See Merges \& Nelson, supra note 7 at 875-77. A recent paper provides theoretical support for this aspect of the Merges-Nelson model, although suggesting an expansion to dcal more fully with the case of a basic invention, which itself has few applicatious, but which leads to a host of signifieant improvements. Howard F. Chang, Patent Scope, Antitrust Policy, and Cumulative Innovation, Harvard Program in Law and Economics Discussion Paper (Sept. 15, 1991).

57 See, e.g., Farok J. Contractor, International Technology Licensing: Compensation, Costs, and Negotiation 105 (1981) (transfer costs averaged over $\$ 100,000$ for licensing deals studied); von Hippel, supra note 54, at 48 (summarizing empirical studies finding generally low net returns from licensing); David J. Teece, The Multinational Corporation and the Resource Cost of International Technology Transfer 44 (1976) (transfer costs constituted 20\% of total project costs in international projects studied) [hereinafter Teece, Multinational Corporation]. More subtle transaction costs, such as possible opportunistic behavior, are described in Bidault, supra note 55, at 127, and David J. Teece, Profiting from Technological Innovation: 
are transferred..$^{58}$ Moreover, various studies indicate that transaction costs tend to be very high if hicenses are tailored to particular hicensees. It is inuch simpler to grant roughly identical hicenses to all who will pay a standard rate, ${ }^{59}$ a practice that would inake it difficult to craft individual deals with potential improvers.

The foregoing discussion isolates several features of technical advance that differ from those imphicit im the Grady-Alexander thesis: pioneer inventors with constrained foresight, and hence less-thanoptimal improveinent developinent potential; inherent gains froin the pursuit of improvements by multiple mventive entities; and the possibility of wasted resources and overlooked opportunities due to the transaction costs of dealings between an imitial inventor and inventors of improveinents. If these features more accurately describe the environment for follow-on imventions, they suggest substantial limitations to the desirability of structuring patent policy around the theme of reducing rent dissipation at the improvement stage. Indeed, they suggest an altogether different view of the matter: that competition in the inarket for improvements is a value-creating, not value-depleting activity. ${ }^{60}$ They suggest, in other words, that a coinpetitive market to capture improvement rents is superior to the "rent control" advocated by Grady and Alexander.

Implications for Integration, Collaboration, Licensing and Public Policy, 15 Res. Pol'y 285, 294 (1986) [heremafter Teece, Profiting].

58 In addition to the studies by Teece and Contractor cited supra note 57 , this point is illustrated by the terms of a broad cross-licensing agreenent between DuPont and Imperial Chemical Industries, Ltd. of Great Britain. The agreement provided for blanket hicensing of all patents owned by the two companies, but "there was a clause allowing either party to remove a 'major invention' from the agreement altogether, so that they could make special terms." 2 W.J. Reader, Imperial Chemical Industries: A History 52-53 (1975).

59 See Richard E. Caves, Harold Crookell \& J. Peter Killing, The Imperfect Market for Technology Licenses, 45 Oxford Bull. Econ. \& Stat. 249, 260-62 (1983) (firms relying heavily on licensing revenues tend to adopt a set of standard licensing clauses). A group led by Edwin Mansfield of the University of Pennsylvania reached the same general conclusion after conducting a similar empirical study. See Edwin Mansfield et al., Technology Transfer, Productivity, and Econonic Policy (1982).

60 In this sense, inventions are the ultimate form of Lockean property: they have value solely because of the labor imput necessary to create them. To the extent this labor leads to elaborations and extensions of an initial inventive principle, it adds value. And to the extent that multiple, coinpetitive laborers can be expected to find more valuable iniprovements and applications for an mitial invention than the original inventor working alone, it suggests this added value ought to be encouraged and rewarded with a property right. On the Lockean view of property, see Edwin C. Hettinger, Justifying Intellectual Property, 18 Phil. \& Pub. Aff. 31 (1989); Alan Ryan, Property and Pohtical Theory 14-48 (1984). 


\section{RENT Dissipation AND SECRECY}

Throughout their article, Grady and Alexander refer to the possibility of wasteful expenditures to inaintain secrecy. For instance, in discussing the different scope of claims for "self-revealing" physical inventions, such as the eraser pencil, and "coinplex processes," they state that inachines and manufacturers encounter a higher standard of patentability than chemical processes. They approve of this treatment, because "[r]ent dissipation through the inaintenance of secrecy is only possible with inventions that do not reveal theinselves upon being marketed." 61 This point builds on an earlier discussion, where the authors assert that "an efficient patent systein should afford less extensive protection when private efforts at secrecy are least possible."62 The idea seeins to be that where secrecy is possible, firms will invest in it; to avoid these investinents, which add no social value, patents inust be granted.

The notion of taking secrecy costs into account when assessing patent doctrines is fascinating. In general, this portion of the GradyAlexander thesis holds great promise. But there are several problems with the way this topic is handled by the authors. First, recent einpirical studies conclude that where secrecy is superior to patent protection, secrecy is the preferred forn of protection. ${ }^{63}$ Thus, there is hittle chance that the patent systein can forestall investınents to maintain secrecy. A firm will inake self-interested investınents in secrecy if they are worthwhile, regardless of net social welfare. Note as well that here the authors depart froin their efforts to keep their piece inerely descriptive. The contrary thrust of current law lends a norinative cast to this aspect of their thesis. It is well-known, for instance, that process inventions are easier to keep secret than product inventions. Yet the requirements for patenting a process are precisely the saine as for a product. If Grady and Alexander were correct, we

61 Grady \& Alexander, supra note 1, at 342.

62 Id. at 318.

${ }^{63}$ Richard C. Levin, Alvin K. Klevorick, Richard R. Nelson \& Sidney G. Winter, Appropriating the Returns from Industrial Research and Developinent, in 3 Brookings Papers on Economic Activity: Special Issue on Microeconomics 783 (Martin N. Bailey \& Clifford Winston eds., 1987) (reporting results of extensive einpirical survey of research and development personnel at U.S. corporations, finding that in many industries, research personnel reported that trade secrecy and other methods of appropriating returns, such as lead time, were superior to patents, and in soine industries patents scored so low in comparison to these other inethods they were almost irrelevant). 
would expect that processes would face, on average, shightly lower requirements. This would imduce process imventors to disclose, savmg the wasteful cost of imvestments in secrecy. But in fact the same requirements apply to processes and products, and thus, there is no extra inducement to process imventors.

Second, puttimg aside the empirical data, it might be argued that Grady and Alexander have it backward-that in fact patents ought to be easier to obtam where secrecy is least possible. They emphasize that where secrecy is not available, society need not worry about wasteful investments to keep mventions secret. ${ }^{64}$ But this iguores the fact that without some form of protection-patents or trade secrets, for imstance-firms will not undertake research that could help competitors. Grady and Alexander state that investments im secrecy "protect the private reward for innovation," but "dissipate the social benefit from an innovation."65 This seems unduly dismissive, given that "protect[img] the private reward for innovation" is thought to be the cornerstone rationale of the entire patent system. ${ }^{66}$

Indeed, the patent system might do well to follow the general lead of Grady and Alexander im this regard, and begin to take mto account the specific characteristics of imdustries or mdustry groups. ${ }^{67}$ One such characteristic is the "regime of appropriability," or the means available to firms in the industry for capturing the value from their innovations. ${ }^{68}$ Surely an industry where trade secrets were not effective would argue that patent protection ought to be at least as easy to obtam as im industries where secrecy was effective. Without patents, presumably fewer innovations would be imtroduced in these imdustries. Unless there was some reason to suspect that the average social value of inventions in these industries was lower than the overall average, it would inake poor policy to make it even harder to protect inventions by raising the standard of patentability.

64 Grady \& Alexander, supra note 1, at 318.

65 Id. (emphasis added).

66 Id.

67 Merges \& Nelson, supra note 7, features some attempts along these lines. Also, I am working on a paper describing the economic rationale behind the standard of patentability, emphasizing that the standard ought to be adjusted in some industries due to special characteristics of the research and developinent environment. See Merges, supra note 18.

68 On the notion of appropriability regimes, see Teece, Profiting, supra note 57, at 287. 
Two final thoughts on the model imphicit in the Grady-Alexander approach are in order. The first concerns its treatment of technological signaling. The authors point to several situations in which some invention or technical solution was too good or too elegant to be improved upon. As a paradigmatic example they cite the eraser pencil, ${ }^{69}$ but other innovations, such as the idea of using ether to anesthetize patients, ${ }^{70}$ also fall into this category. Obviously the follow-on activities inspired by such dissimilar innovations will vary widely. It seems that some ideas Grady and Alexander label as "elegant" will signal few immediate improvements, but proinpt a plethora of applications-many of which will be (or should be) patentable. Grady and Alexander seem unconcerned about the race for apphications that might follow an unimprovable discovery, such as a new principle of nature. $^{71}$

Second, it is not always clear how many apphications or improvements a particular invention might lead to when the patent apphication is filed. In some cases, such as the pencil eraser, it will be clear that the invention "signals" only a limited range of improvements. But im others, it may take some time before one can assess whether the imvention "signals" a wide array of improvements. Where this is true, it will be difficult to make initial decisions regarding patentability using the rent dissipation framework. Rent dissipation may be a more useful organizing principle for infringement cases, because they usually come later in the history of an invention, when the extent of signaling may be more clear. For rent dissipation to be a useful organizing principle, it must be expanded to take account of current

69 Grady \& Alexander, supra note 1, at 330-32 (discussing Reckendorfer v. Faber, 92 U.S. 347 (1875)).

70 Id. at 325-27 (discussing Morton v. New York Eye Infirmary, 17 F. Cas. 879 (S.D.N.Y. 1862) (No. 9,865)).

71 For example, the rapid entry of firms seeking applications of the newly discovered phenomena of monoclonal antibodies in biotechnology, or the race to commercialize new "high temperature" superconductors, closely resemble races to improve basic inventions such as optical fibers or magnetic recording media. See, e.g., Margaret B.W. Graham, The Business of Research: RCA and the Videodisc 91-103 (1986) (magnetic recordimg media); Robert M. Hazen, The Breakthrough: The Race for the Superconductor (1988); Robert Pool, Superconductor Patents: Four Groups Duke It Out, 245 Sci. 931 (1989).

72 Even as regards the subject matter of the Rubber-Tip Pencil Co. case-attacliable pencil erasers-some improvements followed. See Henry Petrovski, The Pencil (1990), for a fascinating description. 


\section{doctrine, which distinguishes in subtle ways between initial enable- ment and subsequent infringeinent. ${ }^{73}$}

73 Grady and Alexander deflect this criticism to some extent by observing that patent cases usually reach the courts only after an invention has had some time to cast a technological signal. Grady \& Alexander, supra note 1, at 320. This observation has some force in the context of infringement actions where signaling issues can be settled on the facts. When applicants appeal adverse rulings by the Patent Office, however, courts must inevitably guess at an invention's likely future impact.

Patent doctrine is sensitive to the distinction between initial enablement and later - infringement. Enablement must be established only as of the date the inventor filed for her patent. An inventor can properly claim subject matter that later turns out to be beyond her actual research, so long as her research enables one skilled in the art to make and use her claimed invention as that invention was understood as of the filing date. See, e.g., Phillips Petroleum Co. v. United States Steel Corp., 865 F.2d 1247 (Fed. Cir. 1989). This creates an interesting conundrum: That an improveinent invention may both be nonobvious over a preceding "basic" invention (and thus be patentable), yet infringe that basic invention. The conundrum arises because the nonobvious (improvement) invention must come within the claims of the preceding (basic) invention to infringe it, and therefore that preceding invention must enable the inprovement, as it must enable any embodiment falling within the claims. But how can an improvement simultaneously be enabled by a basic invention, yet be nonobvious in light of that basic invention?

The answer is in the temporal disparity between enablement and nonobviousness. Enablement is measured as of a patent's filing date. Thus, the basic imvention will be judged enabling if its teachings are sufficient to enable its claims as of the filing date. Nonobviousness, on the other hand, is measured as of the date of invention. Thus, the iniprovement will be nonobvious if it was an unpredictable advance as of its date of invention.

To understand why this temporal disparity matters, consider the example of a basic invention - call it the invention of fuzzballs. The first creator of fuzzballs will be allowed to claim as a product all fuzzballs, limited only by the prior art on fuzzballs. Let us imagine the patent application on the basic fuzzball invention is filed in year one. This application will be tested for enablement as of the year one filing date. If the applicant enables the art to make fuzzballs-as that term is understood as of the filing date-the claim will be allowed. Thus, if the creator of fuzzballs recites in her specification only examples of fuzzballs made from wool and cotton, this in no way limits her claim to these embodiments. It is sinuply the case that as of the filing date, these are the only known fuzzballs. We do not say that slie lias enabled fuzzballs generally-it is simply that the term fuzzballs only includes these two types, as far as anyone knows as of the filing date.

Now imagine a later inprovement: the imvention of fuzzballs made from synthetic fibers, by another inventor, in year two. If the synthetic fuzzballs are accused of infringement, what will a court find? A natural defense for the inventor of synthetic fuzzballs will be that the first inventor's "all fuzzballs" claim is not enabled by her specification. And if the second inventor has received a patent on her iniproved fuzzballs, this will, in her opinion, bolster her argument. For how could her synthetic fuzzballs be both nonobvious over the basic fuzzball patent, and an infringement of that patent, at the same time?

The key is that the content of the term fuzzball is measured as of different dates. The claim of the first patent to "all fuzzballs" is measured as of the filing date for that patent. Because the improvement fits that phase, as it was understood at that (earlier) date, the improvement is enabled. See, e.g., id. The strange thing is that the inventive content of the inuprovement is measured as of its invention date (for purposes of nonobviousness; see 35 U.S.C. $\S 103$ (1988)), 


\section{CONCLUSION}

My observations can be summarized in three statements. First, I like the approach the authors have taken; we need inore such atteinpts to synthesize cases and issues im patent law in accordance with overarching theories.

Second, I think the theory liere is a bit too overarching, because it suggests that doctrine is irrelevant-just a gloss-and that wliat is really going on concerns the law's atteinpt to minimize rent dissipation. I, on the otlier liand, believe doctrine matters. It inatters to the outcoine of cases, and it matters in an attempt to syntliesize cases in terms of a theory (nornative or positive). Perliaps some doctrines reflect the rent dissipation concern; as I liave suggested, enablement

but it is compared to the term in the claim to see if it corresponds as of the earlier date. It is as if someone asked on the filing date in year one, "Could you make a fuzzball with this patent," where fuzzballs are made only of wool and cotton. The answer on the filing date would be yes. But the key is: We do not change the question when we ask it later. So when the later inventor discovers that fuzzballs can be inade with synthetic fibers, we do not ask whether the basic patent filed in year one enables the making of synthetic fuzzballs. We continue to ask whether it enabled the inaking of all fuzzballs, where the content of the term fuzzballs is ineasured as of the date of the original invention.

Thus, the definition of fuzzballs used in the question, "Did you enable the inaking of all fuzzballs" does not change over time, whereas the real working content of the phrase does continue to change, refiecting the inevitable growth of fuzzball technology. In this way, contributions which expand our understanding of the term "fuzzballs" are patentable, yet the test of whether the original claim enables the making of "all fuzzballs" is frozen in time. Thus can a basic patent both enable a later invention, yet not make that invention obvious. This is of course the common situation of blocking patents. See B.G. Corp. v. Walter Kidde \& Co., 79 F.2d 20, 22 (2d Cir. 1935) (Hand, J.). For inore on this "temporal paradox," sec Merges, supra note ${ }^{*}$, at ch. 6 .

In terms of the rent dissipation model, signaling appears to be measured only as of the filing date. Thus, perhaps Grady and Alexander would not permit blocking patents to issue. This would be unfortunate, as it would dispense with a property rights regime that ealibrates in a rough way the reward to the inventive contribution. If, on the other hand, these authors wish to retain the possibility of blocking patents, they necd to refine the notion of signaling to take account of the temporal paradox described here.

In this connection, it is worth noting that the Grady-Alexander thesis leads to an interesting result: either grant broad patents, or deny patentability altogether. The problem with this is that it forces a binary, all or nothing decision on the patent system. Together with my coauthor Richard Nelson, I have suggested elsewhere that it is perhaps preferable to use the various doctrimes that determine the scope of a patent's claims to craft a property right with an appropriate dimension in each case. See Merges \& Nelson, supra note 7. Thus, rather than put the emphasis on whether a broad patent will issue, or none at all, we might instead conceive of the problem as first determining whether some minimum quantum of inventiveness is present, and if so, turn to the task of shaping the precise contours of the right to suit the individual case. 
and nonobviousness are good candidates. But other doctrines are blind to this concern. So even though it may look like a court had rent dissipation in mind when it decided a case, change the facts, and the case coines out the other way under the very doctrine Grady and Alexander suggest is irrelevant-despite the fact that the rent dissipation story stays the same. On this view it is the details of the rules that matter; whatever rent dissipation effects the rules produce in a given case are only artifacts of the apphication of the law. Accordingly, one who is concerned that rent dissipation be kept foremost in mind should suggest how minimization of dissipation can be built directly into doctrines.

My last observation is that the rent dissipation approach itself may overestimate the "wastefulness" of competition in the follow-on market for improvements to a basic invention. Although it is clear that a basic invention can reveal a range of clearly obtainable improvements, and that a passel of imitators may spend more resources racing to obtain them than society would deem efficient, it also is clear that there can be a significant cost to cutting off this coinpetition. An inventor who is given very broad scope on a basic invention will seldoin develop as many improvements as she would under competition, or at least not as quickly. Thus, the broad property right needed to constrain wasteful rent dissipation has its own imphicit cost, which might be described as "improvement dissipation." Before we adopt "rent control" in the inarket for improvements, we need to consider this cost as well. 
HeinOnline -- 78 Va. L. Rev. 3821992 